\title{
Adenosine-receptor subtypes: their relevance to adenosine-mediated responses in asthma and chronic obstructive pulmonary disease
}

\author{
R. Polosa
}

Adenosine-receptor subtypes: their relevance to adenosine-mediated responses in asthma and chronic obstructive pulmonary disease. R. Polosa. (C)ERS Journals Ltd 2002.

ABSTRACT: Adenosine administration by inhalation elicits concentration-related bronchoconstriction in subjects with asthma and chronic obstructive pulmonary disease (COPD). The mechanisms of adenosine-induced bronchoconstriction appear to involve a selective interaction with activated mast cells with subsequent release of preformed and newly-formed mediators. Further evidence linking adenosine signalling to asthma and COPD comes from the finding that many cell types that play important roles in the exacerbation of these conditions express adenosine receptors and demonstrate relevant effects through stimulation of these receptors.

Therefore, blockade of these receptors may be a valuable approach to the treatment of asthma and chronic obstructive pulmonary disease. Promising adenosine-receptor targets for novel therapeutics of asthma and chronic obstructive pulmonary disease have recently been identified in a number of inflammatory cell types, including mast cells, eosinophils, lymphocytes, neutrophils, and macrophages. The recent characterisation of the $A_{2 B}$ receptors indicates the human lung mast cell as one of the most strategic cellular targets.

Eur Respir J 2002; 20: 488-496.
Dept of Internal and Specialist Medicine, University of Catania, AscoliTomaselli Hospitals, Catania, Italy.

Correspondence: R. Polosa

Dipartimento di Medicina Interna e

Specialistica

Università di Catania

Ospedale Tomaselli

Via Passo Gravina 187

95125 Catania

Italy

Fax: 39095330707

E-mail: rp5@soton.ac.uk

Keywords: Adenosine receptors, asthma, bronchoconstriction, chronic obstructive pulmonary disease, mast cell

Received: February 122002

Accepted after revision: March 262002
Adenosine has been suggested to play a role in inflammatory airway diseases such as asthma and chronic obstructive pulmonary disease (COPD) [1-3]. Elevated levels of adenosine have been measured in the airway lining fluid of patients with asthma and COPD when compared to normal controls [4]. In sensitised rabbits, high concentrations of adenosine have been reported in the lung-lavage fluid after allergen challenge [5], whereas in transgenic mice, adenosine-receptor transcripts are increased in association with lung inflammation and increased airways hyperresponsiveness [6]. Adenosine administration by inhalation elicits concentration-related bronchoconstriction in subjects with asthma and COPD [7, 8], whereas the nucleoside has no discernable effect on airway calibre in normal individuals. Since these initial observations were made, considerable effort has been directed toward revealing the fine mechanisms of adenosine-induced bronchoconstriction; these appear to involve a selective interaction with activated mast cells, with subsequent release of preformed and newly-formed mediators [9-13] (fig. 1).

There is now increasing evidence that evaluation of airway responsiveness by adenosine-induced bronchoconstriction may be valuable in differentiating asthma from COPD, monitoring anti-inflammatory therapy in asthma, surveying disease progression, and assessing disease activity in relation to allergic airway

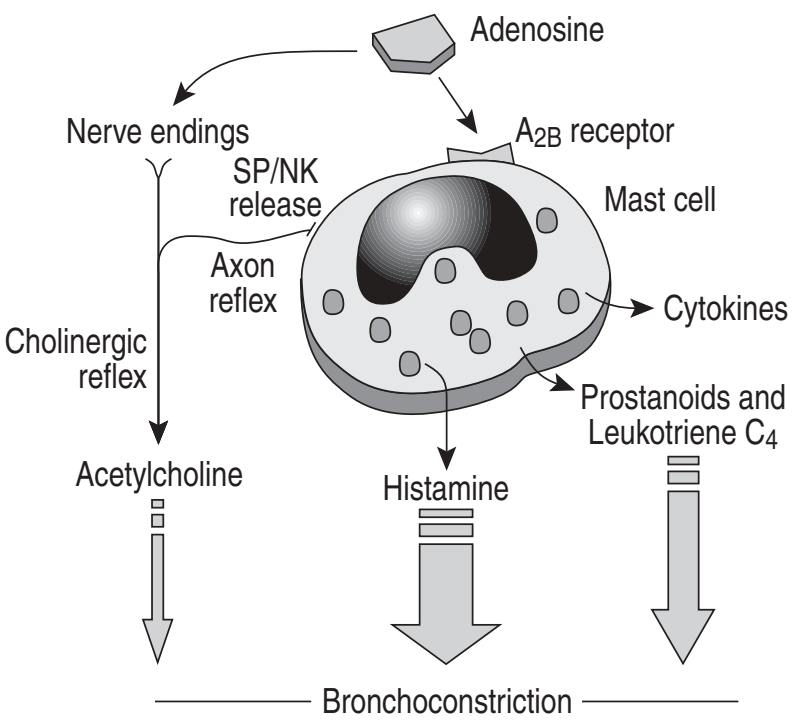

Fig. 1.- Proposed mechanisms by which adenosine cause bronchoconstriction in asthma and chronic obstructive pulmonary disease. Please note that mast-cell derived mediators are largely implicated in the airway response to adenosine (largest arrow), whereas the role of neural pathways is negligible (smallest arrow). SP: substance P; NK: neurokinins.

inflammation. In particular, adenosine responsiveness is closely associated with allergic airway inflammation, as recently demonstrated in studies of subjects 
with asthma and active allergic rhinitis, in which airways responsiveness to adenosine $5^{\prime}$-monophosphate (AMP), but not methacholine, was strongly correlated with sputum eosinophilia [14, 15].

Further evidence linking adenosine signalling to asthma and COPD is provided by the finding that many cell types that play important roles in the exacerbation of these conditions, express adenosine receptors and demonstrate relevant effects through stimulation of these receptors. These include mast cells [16, 17], eosinophils [18], lymphocytes [19], neutrophils [20], and macrophages [21, 22].

In this article, evidence of a pathophysiological role of adenosine-receptor signalling in chronic inflammatory airway diseases, such as asthma and COPD, is reviewed.

\section{Cellular mechanisms of adenosine-induced bronchoconstriction in asthma and COPD}

Even if adenosine signalling is likely to involve many cell types with demonstrated relevant effects in asthma and COPD, only in recent times the bronchoconstrictor response that follows adenosine inhalation has attracted the attention of researchers in respiratory pharmacology and physiology. To date there are no adenosine antagonists that have been accepted for use in humans, but alternative pharmacological approaches have suggested that it is unlikely that adenosine acts directly on smooth muscle cells in vivo, but indirectly through activation of purinoreceptors expressed on intermediary inflammatory cells, such as mast cells, or on afferent nerve endings (fig. 1).

\section{Neural pathways}

Activation of neural pathways is suspected to contribute to the contractile airway response to adenosine. The possibility of a reflex cholinergic component was originally indicated by data from studies in inbred rats [23] and later confirmed in a clinical investigation in which premedication with high doses of the anticholinergic drug ipratropium bromide administered by inhalation significantly attenuated the bronchoconstrictor response to AMP in asthma [24]. Further support for a neural contribution to AMPinduced bronchoconstriction comes from observations made with frusemide and bumetanide, two loop diuretics that are also likely to act by modulating sensory nerve responses in the airways [25]. Inhalation of these drugs substantially inhibits the bronchoconstrictor response of AMP without affecting the response to histamine [26-28]. In guinea pigs in vivo the synthetic adenosine analogue, 2-chloroadenosine, provoked bronchoconstriction that was attenuated by capsaicin [29]. Moreover, in BDE rats, adenosine elicits increased pulmonary resistance by stimulating neuropeptide-producing nerves via prior mast-cell activation [30]. These observations indicate that the release of contractile neuropeptides from sensory nerve endings might be of some importance in mediating the airway effects of purine derivates. In order to probe this hypothesis, a protocol of repeated bradykinin bronchoprovocations as a model of neuropeptide depletion in humans was used. Repeated challenge with bradykinin, sufficient to cause a 15 -fold reduction in response to the kinin, results in some attenuation of a subsequent AMP response, without affecting airway responsiveness to histamine [31]. However, inhibition of neutral endopeptidase (NEP) by inhaled phosphoramidon failed to elicit any significant enhancement of the bronchospastic response provoked by AMP, suggesting that release of endogenous neuropeptides has little importance in the airway response to adenosine [32]. The role of neural pathway in adenosine-induced bronchoconstriction in COPD patients has not been fully addressed. However, a recent study by REUTGERs et al. [33] showed no significant effect on AMP responsiveness after inhaled ipratropium bromide in patients with COPD, implying that vagal-nerve activation does not play a role. This contrasts with the findings in asthmatic patients, where ipratropium bromide caused an $\sim 2.5$-fold increase in the provocative concentration of AMP causing a $20 \%$ fall in the forced expiratory volume in one second (PC20) [24]. It is possible that in asthma, AMP stimulates mast cells to release histamine, which causes an additive effect via vagal-nerve stimulation. In COPD, histamine release may be smaller and inadequate for the stimulation of vagal-nerve endings during AMP challenge.

\section{Mast cells}

The fact that mast cells are likely to play a major role in the bronchoconstrictor response to inhaled adenosine, both in asthma and in the active inflammatory phase of COPD, is indicated by in vitro studies in which adenosine markedly enhances the release of histamine and other newly-formed spasmogens from human lung mast cells obtained by enzymatic dispersion [34, 35] and bronchoalveolar lavage [36]. Taken together, the above evidence indicates that the mast cell may be involved in the bronchoconstrictor response to inhaled adenosine, principally via release of granule-derived preformed mediators. What in vivo evidence is there to support this? In asthma, the mastcell inhibitors, sodium cromoglycate, nedocromil sodium and salbutamol have been found to attenuate AMP-induced bronchoconstriction to a greater extent than bronchoprovocation provoked by the smoothmuscle agonist, methacholine [37, 38]. In addition, premedication with the potent $\mathrm{H}_{1}$-histamine receptor antagonists, terfenadine and astemizole, has been shown to inhibit the acute bronchoconstrictor response to inhaled AMP in asthmatic and COPD patients [33, 39, 40]. More direct evidence that histamine released from airway mast cells are critical for adenosineinduced responses has come from work in which direct instillation of AMP into asthmatic bronchi [10] or into the nose of patients with allergic rhinitis [12] resulted in significant increases in the concentration of histamine and tryptase in their lavage fluid.

Since $\mathrm{H}_{1}$-histamine receptor antagonists do not completely inhibit AMP-induced bronchoconstriction, 
the role of other mast-cell derived mediators has to be considered. In addition to preformed mediators, the role of other mast cell-derived mediators has to be considered. The role of prostanoids in the response to AMP is supported by the demonstration that potent cyclo-oxygenase inhibitors, such as indomethacin and flurbiprofen, attenuate the constrictor effect of the nucleotide [9, 41]. In addition, lysine aspirin administered by inhalation causes some attenuation of the AMP response [11]. More direct evidence of the role of newly-generated mediators has come from the study by Polosa et al. [10]. In addition to the rise in histamine and tryptase levels in the bronchoalveolar lavage fluid, an even greater increase in the prostaglandin $\mathrm{D}_{2}\left(\mathrm{PGD}_{2}\right)$ concentrations was found. Recently, premedication with Abbott's (ABT761) [42], a potent 5-lipoxygenase inhibitor, and the selective cysteinyl leukotriene receptor 1 (Cys $\left.\mathrm{LT}_{1}\right)$ receptor antagonist montelukast [13], has been shown to attenuate the acute bronchoconstrictor response to inhaled AMP, thus suggesting a role for spasmogenic leukotrienes.

These studies reasonably support the concept that mast-cell derived mediators are largely implicated in the bronchoconstrictor response to adenosine in asthma and COPD, which is probably the result of an interaction of the nucleoside with specific mast-cell surface receptors (fig. 1). However, the specific mastcell adenosine-receptor subtype involved in the response is not known.

\section{Adenosine metabolic pathways}

Adenosine is a nucleoside consisting of the purine base, adenine, in glycosidic linkage with the sugar, ribose. Most extracellular adenosine derives from the enzymatic cleavage of the nucleotide AMP by a plasma membrane 5'-nucleotidase [43] (fig. 2). Although some of this AMP is generated from extracellular adenosine triphosphate (ATP), most is probably derived from intracellular AMP as it diffuses down its concentration gradient out of the cell and thereby encounters the $5^{\prime}$-nucleotidase located in the cell membrane. Intracellular AMP is mainly derived from the cleavage of adenosine diphosphate (ADP) and ATP during energy generation. Other pathways for the production of AMP do exist, but are quantitatively much less important. Although most intracellular AMP is normally reconverted to ADP and ATP, under conditions of high energy demand and/or hypoxia it is metabolised to adenosine by $5^{\prime}$ nucleotidase [44]. This may occur during inflammation when a large number of infiltrating inflammatory cells compete for a limited oxygen supply. Intracellular levels of adenosine are kept low principally by conversion to AMP by the enzyme adenosine kinase [45], but when energy demands are greater adenosine is also degraded to inosine and hypoxanthine by adenosine deaminase [46]. Extracellular adenosine diffuses back into the cell through the operation of an energy-independent nucleoside transporter [47]. Since intracellular adenosine levels are kept low, there is an inwardly directed concentration gradient (fig. 2).

\section{Adenosine-receptor subtypes: a historical perspective}

Once it is generated, extracellular adenosine elicits a variety of cellular responses relevant to asthma and COPD that are mostly mediated through interaction with G-protein coupled receptors on the surface

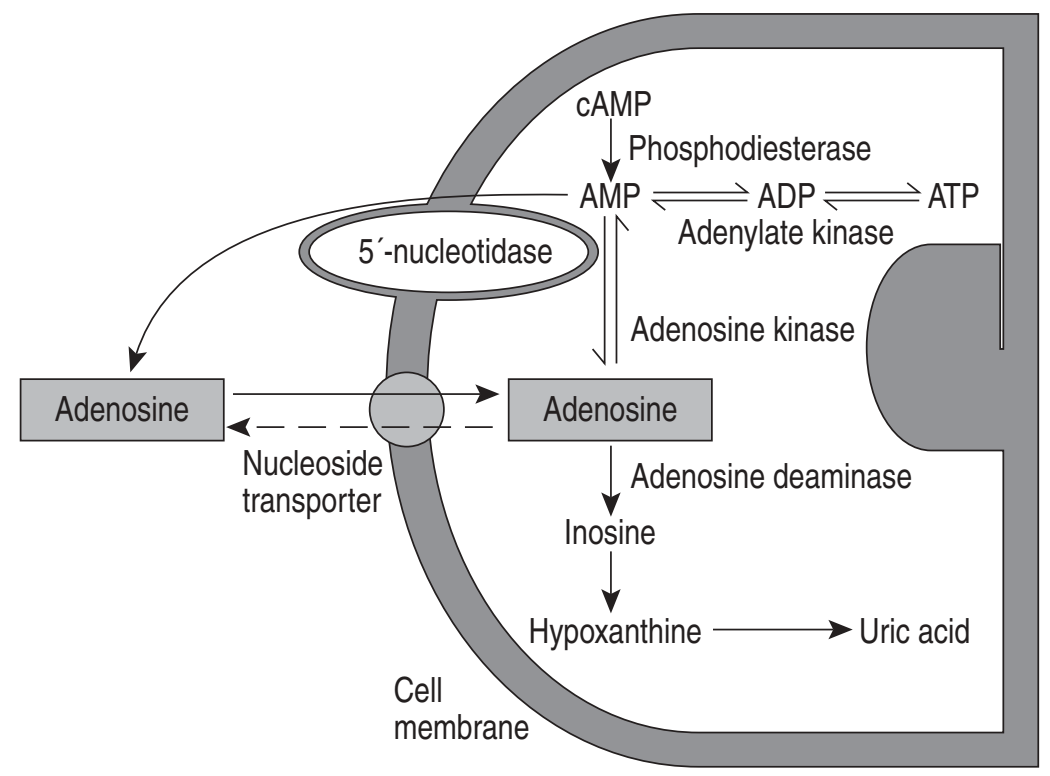

Fig. 2.-During the catabolism of high energy adenosine phosphates (adenosine triphosphate (ATP), adenosine diphosphate (ADP)), intracellular adenosine 5'-monophosphate (AMP) is formed and shortly reconverted to ADP and ATP as part of the energy cycle. However, under conditions of high-energy demand, AMP cannot be reconverted and it is metabolised to adenosine by a plasma membrane 5 '-nucleotidase. Intracellular levels of adenosine are kept low principally by its conversion to AMP by the enzyme adenosine kinase, but when energy demands are greater, adenosine is also degraded to inosine and hypoxanthine by adenosine deaminase. Extracellular adenosine diffuses back into the cell through the operation of an energy-independent nucleoside transporter. cAMP: cyclic AMP. 
of target cells [48]. The ability of the adenosineuptake inhibitor, dipyridamole, to enhance adenosineinduced effects led to the suggestion that its actions are likely to be mediated through stimulation of specific receptors located on the cell surface [49, 50]. In addition, theophylline, a drug that is frequently used for resolution of airway obstruction in asthma and COPD, is known to attenuate adenosine-induced bronchoconstriction through an adenosine receptor antagonistic activity at therapeutic plasma levels $(20-120 \mu \mathrm{M})$. In the early $1980 \mathrm{~s}$, understanding of adenosine receptors was simply based on the activity of "specific" agonists/antagonists and limited to a division between $A_{1}$ receptors (which decreased intracellular cyclic AMP (cAMP) levels) and $\mathrm{A}_{2}$ receptors (which increased intracellular cAMP) [51, 52]. Suggestions that the adenosine $A_{1}$ receptor antagonistic activity of theophylline might explain its clinical potency received a blow when it was discovered that another xanthine, enprofylline, was just as effective as theophylline clinically but lacked adenosine $\mathrm{A}_{1}$-receptor antagonistic activity. Enprofylline was also able to block adenosine-induced bronchospasm in asthmatic subjects and, despite its lack of $\mathrm{A}_{1}$ receptor antagonistic activity, was more potent in this respect than theophylline. This paradox was at that time considered to be evidence against adenosine-receptor antagonism as an explanation of the clinical efficacy of xanthines. In the 1990s, information about new adenosine-receptor subtypes provided a possible explanation for the "enprofylline paradox". The application of molecular cloning techniques has expanded the range of known adenosine receptors to include the $A_{3}$ receptor [53] and the $A_{2 B}$ receptor (the originally described $A_{2}$ receptor now being designated $\mathrm{A}_{2 \mathrm{~A}}$ ) [54]. Enprofylline (as well as theophylline) inhibited ligand binding to the human recombinant adenosine $\mathrm{A}_{2 \mathrm{~B}}$ receptor with a $\mathrm{Ki}$ of $\sim 7 \mu \mathrm{M}[55,56]$, a value which lies well within the typical plasma levels of enprofylline after therapeutic dosage $(5-25 \mu \mathrm{M})$. The stable adenosine analogue 5 '-N-ethylcarboxamidoadenosine (NECA)-induced release of interleukin (IL)-8 from the human mastcell line HMC-1, which appeared to be predominantly mediated over the $\mathrm{A}_{2 \mathrm{~B}}$ receptor [57], was blocked by enprofylline, although the reported study did use a relatively high concentration of the drug $(300 \mu \mathrm{M})$ [58]. Theophylline was also shown to block NECAinduced cAMP accumulation in Chinese hamster ovary $(\mathrm{CHO})$ cells transfected with human $\mathrm{A}_{2 \mathrm{~B}}$ receptors with a $\mathrm{Ki}$ of just $<7 \mu \mathrm{M}$ [59]. However, the fact that enprofylline has little affinity with the $\mathrm{A}_{1}$ receptor does not mean that the $A_{1}$ receptor has no role in asthma. Indeed, an antisense oligonucleotide against the adenosine $A_{1}$ receptor is under investigation for just this purpose [60].

A detailed characterisation of adenosine-receptor subtypes has been conducted in human lung tissue and isolated human bronchoalveolar lavage cells in an attempt to define their pharmacological role in adenosine-induced responses. However, the limited specificity of available adenosine-receptor agonists and antagonists [48, 59, 61] makes identifying the adenosine-receptor subtypes involved a difficult task.
Fortunately, however, antibodies or in situ hybridisation probes have recently become available for the different human adenosine-receptor subtypes. These studies can provide a more certain identification of receptor subtype as well as information on localisation.

\section{Adenosine $A_{1}$ receptors}

Description of adenosine $\mathrm{A}_{1}$-receptor expression and distribution has been widely carried out in mammals. Binding data indicate that the $A_{1}$ receptor is not particularly abundant in normal human lung, but its presence, possibly associated with nerves, is supported by functional studies. Adenosine $\mathrm{A}_{1}$ receptors are present on human neutrophils, activation of which promotes chemotaxis [62] and increased adherence to endothelial cells $[63,64]$. With specific regard to asthma, it has been shown that rabbits immunised at birth with antigen develop airways hyperreactivity to adenosine by a mechanism involving upregulation of the $A_{1}$ receptor $[65,66]$. In an elegant extension of these studies, combined pharmacological and antisense approaches confirmed that adenosine-receptor mediated bronchoconstriction in the rabbit is mediated by the $A_{1}$ receptor [67]. Using antisense oligodeoxynucleotides targeted against the $A_{1}$ receptors of the lung to reduce their numbers, they were also able to show that sensitised animals without the $A_{1}$ receptor manifested a reduced bronchoconstrictor response to allergen challenge [67]. In a recent study of mice lungs, all four of the adenosine receptors have been detected, with $\mathrm{A}_{1}$-receptor transcripts being the most abundant [6]. These authors also found a significant increase in transcript levels of the $A_{1}, A_{2 A}$ and $\mathrm{A}_{2 \mathrm{~B}}$ receptors in the lungs of adenosine-deaminase deficient mice, which was seen in association with lung inflammation and increased airways hyperresponsiveness. Although these data lend some support to the evidence of adenosine $A_{1}$ receptor as a potential therapeutic target for allergic asthma or COPD, at the present time, there is no confirmation that this receptor subtype is involved in airway responses to adenosine in humans.

\section{Adenosine $\mathbf{A}_{2 \mathrm{~A}}$ receptors}

Both $\mathrm{A}_{2 \mathrm{~A}}$ and $\mathrm{A}_{2 \mathrm{~B}}$ receptors have been identified by reverse-transcriptase polymerase chain reaction (RTPCR) and in human bronchoalveolar lavage mast cells $[57,68]$. The subunit s of G-protein (Gs)-coupled adenosine $A_{2 A}$ and $A_{2 B}$ receptors are distinguished by their high and low affinity, respectively, for adenosine [2]. The $A_{2 A}$ receptors most relevant to human lung disease are those expressed on mast cells [57, 68], neutrophils [69] and T-cells [70]. In contrast to $A_{2 B}$ receptors, $A_{2 \mathrm{~A}}$ activation results in suppression of histamine and tryptase release from human mast cells $[68,71,72]$. This could provide a balanced control mechanism. It is possible that at low concentrations of adenosine, only the off-signal provided by engagement of the higher affinity $\mathrm{A}_{2 \mathrm{~A}}$ receptors prevails, thus 
a)

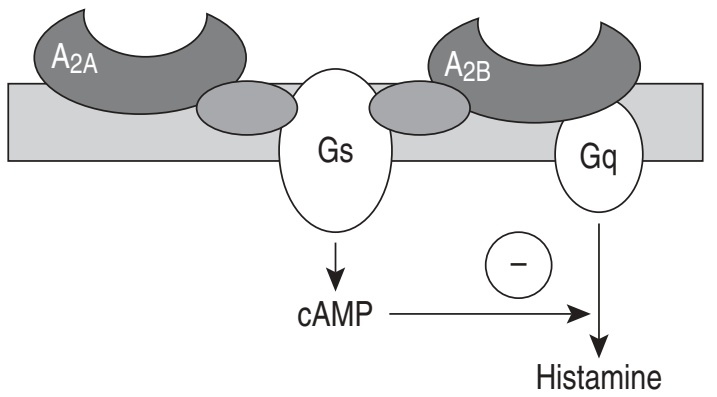

b)

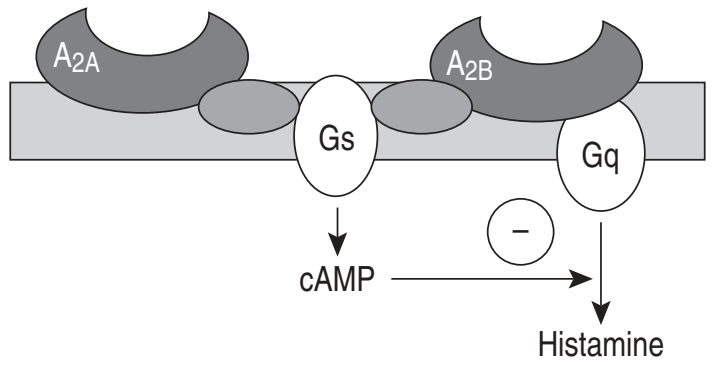

Fig. 3. - Diagram hypothesising the mechanism by which adenosine enhances histamine release from human airway mast cells in asthma. a) Normally, stimulation of the high-affinity $A_{2 \mathrm{~A}}$ adenosine receptor by adenosine leads to the generation of large quantities of intracellular cyclic adenosine 5'-monophosphate (cAMP), which downregulates the biochemical pathways implicated in the release of histamine. b) Possible scenario in asthma, where in the presence of high concentrations of adenosine the relative importance of the low-affinity $\mathrm{A}_{2 \mathrm{~B}}$ receptor becomes greater with prevalent activation of regulatory subunit $\mathrm{q}$ of G-protein coupled receptor $(\mathrm{Gq})$ proteins with significant mastcell degranulation. In addition, downregulation of the subunit s of $\mathrm{G}$-protein coupled receptor (Gs) function leads to a reduction of cAMP generation with subsequent reduced negative modulation on histamine release.

downregulating mast-cell mediator release (fig. 3a). Conversely, in situations in which high concentrations of adenosine are reached, such as in asthma and COPD [4], the relative importance of the low-affinity $\mathrm{A}_{2 \mathrm{~B}}$ receptor becomes greater with significant mastcell degranulation (fig. 3b). In addition to its putative role on human lung mast cells, adenosine appears to exert important effects on neutrophils. It is well known that stimulation of $\mathrm{A}_{2 \mathrm{~A}}$ receptors abates neutrophil adherence to the endothelium [63], prevents upregulation of integrin expression on formylMet-Leu-Phe-stimulated neutrophils [73] and inhibits degranulation of activated neutrophils and monocytes [74-76]. Therefore, administration of an $\mathrm{A}_{2 \mathrm{~A}}$ receptor agonist might exhibit anti-inflammatory potential in a disease such as COPD, where neutrophil-/monocytemediated tissue injury is strongly implicated. Unfortunately, $\mathrm{A}_{2 \mathrm{~A}}$ receptors have a broad anatomical distribution (table 1) and they are important in mediating a number of responses in other body structures and cell systems, including inhibition of platelet aggregation, vasodilatation and a variety of effects on the central nervous system [78]. A selective topical action in the lung would be necessary to avoid unacceptable side-effects. Conversely, specific antagonists at $\mathrm{A}_{2 \mathrm{~A}}$ receptors may enhance neutrophil activation and aggravate inflammation.

\section{Adenosine $\mathbf{A}_{2 \mathrm{~B}}$ receptors}

Recently, the application of molecular cloning techniques identified the human adenosine $\mathrm{A}_{2 \mathrm{~B}}$ receptor [54]. The $A_{2 B}$ receptor is structurally closely related to the $\mathrm{A}_{2 \mathrm{~A}}$ receptor, and like the $\mathrm{A}_{2 \mathrm{~A}}$ receptor, could raise intracellular cAMP when activated. Functionally, however, it appears to be very different from the $A_{2 \mathrm{~A}}$ receptor, which suggests that signaltransducing systems other than those directly linked to adenyl cyclase might be more important for its function [79]. The adenosine $A_{2 B}$ receptor has recently been identified immunochemically in human bronchial epithelium [80] and functional $\mathrm{A}_{2 \mathrm{~B}}$ receptors have been found in endothelial cells, muscle cells, neurons, glial cells, neurosecretory cells, fibroblasts, and mast cells [57, 81]. Activation of $\mathrm{A}_{2 \mathrm{~B}}$ receptors in the human mast cell line HMC-1 augments IL-8 release per se and potentiates phorbol 12-myristate 13-acetate (PMA)-induced secretion of IL-8 [58]. HMC-1 cells co-express $A_{2 A}$ and $A_{2 B}$ receptors, both of which are coupled with adenylate cyclase through G-proteins, but only $\mathrm{A}_{2 \mathrm{~B}}$ receptors activate $\mathrm{HMC}-1$ cells to release IL-8. Thus, adenosine would contribute to the pathogenesis of inflammatory airways disease by

Table 1. - Pharmacological classification and anatomical distribution of adenosine-receptor subtypes

\begin{tabular}{|c|c|c|c|}
\hline $\begin{array}{l}\text { Receptor } \\
\text { subtype }\end{array}$ & Agonists $\#$ & Antagonists ${ }^{\#}$ & Distribution \\
\hline $\mathrm{A}_{1}$ & $\mathrm{CHA}>\mathrm{NECA}>>\mathrm{CGS} 21680$ & DPCPX $>$ XAC $>$ CGS15943 $>$ SPT & $\begin{array}{l}\text { Heart, adipocytes, respiratory } \\
\text { smooth muscle, neutrophils, } \\
\text { kidney, hippocampus, cortex }\end{array}$ \\
\hline $\mathrm{A}_{2 \mathrm{~A}}$ & $\begin{array}{l}\mathrm{CGS} 21680 \approx \mathrm{NECA}>> \\
\text { CHA }\end{array}$ & $\begin{array}{l}\mathrm{ZM} 241385 \approx \mathrm{SCH} 58261 \approx \\
\quad \text { CGS15943 } \geqslant \text { XAC }>\text { DPCPX }\end{array}$ & $\begin{array}{l}\text { Platelets, neutrophils, vasculature, } \\
\text { pancreas, mast cells, striatum }\end{array}$ \\
\hline $\mathrm{A}_{2 \mathrm{~B}}$ & $\begin{array}{l}\text { NECA }>\text { CHA }>> \\
\quad \text { CGS } 21680\end{array}$ & XAC $>$ CGS15943>DPCPX & $\begin{array}{l}\text { Vascular, intestinal and respiratory } \\
\text { smooth muscle, chromaffin tissue, } \\
\text { mast cells, brain }\end{array}$ \\
\hline $\mathrm{A}_{3}$ & $\begin{array}{l}\text { 2-C1-IB-MECA }>\text { APNEA }> \\
\text { NECA } \approx \mathrm{CGS} 21680\end{array}$ & $\begin{array}{l}\text { MRS1220 } \approx \text { IABOPX }> \\
\text { L268605 }>>\text { XAC }>\text { DPCPX }\end{array}$ & $\begin{array}{l}\text { Testis, kidney, lung, mast cells, } \\
\text { eosinophils, neutrophils, } \\
\text { heart, cortex, striatum }\end{array}$ \\
\hline
\end{tabular}

\footnotetext{
\#: Full details on the adenosine receptor agonists and antagonists and the abbreviations can be found in [77]. >: greater than;
} $>>$ : much greater than; $\approx$ : approximately equal to. 
acting on the mast cell $\mathrm{A}_{2 \mathrm{~B}}$ receptor to enhance the release of proinflammatory mediators [2]. Given that inhaled adenosine only elicits bronchoconstriction in subjects with asthma and COPD [7, 8] and has no effect on the airway calibre of normal individuals, there appears to be an intrinsic difference in the way adenosine interacts with mast cells from patients. Although the response produced in vitro by $\mathrm{A}_{2 \mathrm{~B}}$ receptors in $\mathrm{HMC}-1$ cells appears to mimic the in vivo responses to inhaled adenosine in asthma and COPD, the molecular mechanisms behind the differential responses in asthma/COPD patients compared with normal controls remain to be elucidated. Several mechanisms could explain these discrepancies, including differential coupling of $\mathrm{A}_{2 \mathrm{~B}}$ receptors to intracellular pathways and diversity at the receptor level, such as that based on different levels of affinity for $\mathrm{A}_{2 \mathrm{~A}}$ and $\mathrm{A}_{2 \mathrm{~B}}$ receptors (fig. 3). Although adenosine appears to mediate its effects mainly through adenosine-receptor activation in inflammatory cells, combined functional and radioligand binding studies have demonstrated that human airway smooth muscle is also a direct target of adenosine, with effects determined by differential contributions of time-dependent $A_{2 B}$ and $\mathrm{A}_{1}$ adenosine receptors [82]. Accordingly, the relative distribution and activation of adenosine-receptor subtypes in airway smooth muscle may influence airway function in diseases such as asthma and COPD and warrant consideration in therapeutic strategies that target adenosine receptors or alter nucleotide/ nucleoside levels in the airway.

The argument for $\mathrm{A}_{2 \mathrm{~B}}$-receptor activation being integral to the pathophysiology of asthma and COPD receives further support from consideration of the pharmacological properties of theophylline. Theophylline has affinity for human $\mathrm{A}_{2 \mathrm{~B}}$ receptors at therapeutic blood concentrations but is not selective since it shows similar or lower affinities for both the $A_{1}$ and $A_{2 A}$ receptors. Given the limited role of the adenosine $A_{1}$ and $A_{2}$ receptors outlined above and the fact that therapeutic doses of theophylline have been shown to produce a greater inhibition against the bronchoconstrictor response to adenosine than against histamine [83], blockade of the $A_{2 B}$ receptor seems a plausible explanation for the clinical benefit seen with the drug. Moreover, the methylxanthine phosphodiesterase inhibitor, enprofylline, which has a similar anti-asthmatic activity to theophylline [84], has been recently shown to serve as a selective $A_{2 B^{-}}$ receptor antagonist at therapeutic blood levels [58]. Selective antagonists of the $\mathrm{A}_{2 \mathrm{~B}}$ receptor may provide a more potent and safer alternative to theophylline and enprofylline.

\section{Adenosine $\mathrm{A}_{3}$ receptors}

Both in vitro $[17,85]$ and in vivo $[86,87]$ studies have established that activation of $\mathrm{A}_{3}$ receptors results in mast-cell degranulation and/or enhancement of mast degranulation in response to allergen in a variety of rodent species. However, $\mathrm{A}_{3}$-receptor protein was not found in association with human lung mast cells [18], thus questioning its relevance in the mechanism of adenosine-induced bronchoconstriction in humans.
There is now accumulating evidence that $\mathrm{A}_{3}$-receptor activation modulates functional changes in a variety of human immuno-inflammatory cells. For example, in the human lung, $A_{3}$ receptors are expressed on eosinophils in a relatively high density [88] and mediate inhibition of eosinophil chemotaxis when activated $[18,89]$. In addition, these authors demonstrated that expression of the $\mathrm{A}_{3}$ receptor (messenger ribonucleic acid (mRNA) and protein) was enhanced in the asthmatic lung [18]. Recently, EzeAMUZIE and PHILIPS [90] have shown that these receptors mediate two important anti-inflammatory functions of human eosinophils: the inhibition of the degranulation and suppression of oxygen radical generation. Adenosine $\mathrm{A}_{3}$-receptor activation has also been implicated in: the suppression of tumour necrosis factor (TNF)- $\alpha$ release from human monocytes by endotoxin [91]; the inhibition of neutrophil degranulation induced by endotoxin or TNF- $\alpha$ in whole human blood [76]; and the modulation of $\mathrm{T}$-cell function [92]. These findings have subsequently raised the question of the functional roles of these receptors. It is possible that the high adenosine concentrations found in the lungs of patients with asthma and COPD may be sufficient to produce significant inhibition. In this case, the presence of high levels of adenosine may represent a way for attenuating eosinophilic and neutrophilic inflammation via $\mathrm{A}_{3}$-receptor activation. Thus, selective $\mathrm{A}_{3}$ agonists may be valuable as anti-inflammatory drugs with a useful potential in the treatment of conditions such as asthma and COPD, where activated eosinophils and neutrophils play an important role.

\section{Conclusions}

Recognition of the potential role of adenosine receptors in the pathogenesis of chronic airway inflammatory diseases raises the possibility that blockade of these receptors may be a valuable approach to the treatment of asthma and chronic obstructive pulmonary disease. Promising adenosine receptor targets for novel therapeutics of asthma and chronic obstructive pulmonary disease have been recently identified in a number of inflammatory cell types, including mast cells, eosinophils, lymphocytes, neutrophils, and macrophages. However, the human lung mast cell appears to be the most attractive cellular target because of the unique modulation of its pharmacological characteristics and functional effects in response to inflammatory stimuli. Mast cells are likely to play a major role in the bronchoconstrictor response to inhaled adenosine both in asthma and in the active inflammatory phase of chronic obstructive pulmonary disease. Stimulation of $\mathrm{A}_{2 \mathrm{~B}}$ receptors expressed on the surface of the human lung mast cell is likely to be the main trigger for adenosine-induced bronchospasm. Therefore, development of potent and selective $\mathrm{A}_{2 \mathrm{~B}}$ adenosine-receptor antagonists for use in humans appears particularly beneficial and may further increase knowledge of the role of these receptors in physiological and pathological conditions. 


\section{References}

1. Polosa R, Holgate ST. Adenosine bronchoprovocation: a promising marker of allergic inflammation in asthma? Thorax 1997; 52: 919-923.

2. Feoktistov I, Polosa R, Holgate ST, Biaggioni I. Adenosine $\mathrm{A}_{2 \mathrm{~B}}$ receptors: a novel therapeutic target in asthma? Trends Pharmacol Sci 1998; 19: 148-153.

3. Fozard JR, Hannon JP. Adenosine receptor ligand: Potential as therapeutic agents in asthma and COPD. Pulm Pharmacol Ther 1999; 12: 111-114.

4. Driver AG, Kukoly CA, Ali S, Mustafa SJ. Adenosine in bronchoalveolar lavage fluid in asthma. Am Rev Respir Dis 1993; 148: 91-97.

5. Ali S, Mustafa SJ, Metzger WJ. Adenosine receptormediated bronchoconstriction and bronchial hyperresponsiveness in allergic rabbit model. Am J Physiol 1994; 266: L271-L277.

6. Chunn JL, Young HW, Banerjee SK, Colasurdo GN, Blackburn MR. Adenosine-dependent airway inflammation and hyperresponsiveness in partially adenosine deaminase-deficient mice. J Immunol 2001; 167: 46764685.

7. Cushley MJ, Tattersfield AE, Holgate ST. Inhaled adenosine and guanosine on airway resistance in normal and asthmatic subjects. Br J Clin Pharmacol 1983; 15: 161-165.

8. Oosterhoff Y, de Jong JW, Jansen MAM, Koeter GH, Postma DS. Airway responsiveness to adenosine 5'monophosphate in chronic obstructive pulmonary disease is determined by smoking. Am Rev Respir Dis 1993; 147: 553-558.

9. Phillips GD, Holgate ST. The effect of oral terfenadine alone and in combination with flurbiprofen on the bronchoconstrictor response to inhaled adenosine 5 '-monophosphate in nonatopic asthma. Am Rev Respir Dis 1989; 139: 463-469.

10. Polosa R, Ng WH, Crimi N, et al. Release of mast cell-derived mediators after endobronchial adenosine challenge in asthma. Am J Respir Crit Care Med 1995; 151: 624-629.

11. Crimi N, Polosa R, Magri S, et al. Inhaled lysine acetylsalicylate (L-ASA) attenuates the bronchoconstrictor response to adenosine 5'-monophosphate (AMP) in asthmatic subjects. Eur Respir $J$ 1995; 8: 905-912.

12. Polosa R, Pagano C, Dokic D, Prosperini G, Church MK, Crimi N. Histamine release upon AMP nasal provocation in allergic subjects. Thorax 1999; 54: 230 233.

13. Rorke S, Jennison S, Jeffs JA, Sampson AP, Arshad $\mathrm{H}$, Holgate ST. The role of cysteinyl leukotrienes in AMP-induced bronchoconstriction in asthma. Thorax 2001 (in press).

14. Polosa R, Ciamarra I, Mangano G, et al. Bronchial hyperresponsiveness and airway inflammation markers in nonasthmatics with allergic rhinitis. Eur Respir $J$ 2000; 15: 30-35.

15. van den Berge M, Meijer RJ, Kerstjens HA, et al. PC20 adenosine 5'-monophosphate is more closely associated with airway inflammation in asthma than PC20 methacholine. Am J Respir Crit Care Med 2000; 163: $1546-1550$.

16. Marquardt DL, Walker BA, Heinemann S. Cloning of two adenosine receptor subtypes from mouse bone marrow-derived mast cells. J Immunol 1994; 152: $4508-4515$.
17. Ramkumar V, Stiles GL, Beaven MA, Ali H. The $\mathrm{A}_{3}$ adenosine receptor is the unique adenosine receptor which facilitates release of allergic mediators in mast cells. J Biol Chem 1993; 268: 16887-16890.

18. Walker BA, Jacobson MA, Knight DA, et al. Adenosine $\mathrm{A}_{3}$ receptor expression and function in eosinophils. Am J Respir Cell Mol Biol 1997; 16: 531537.

19. Huang S, Apasov S, Koshiba M, Sitkovsky M. Role of $\mathrm{A}_{2 \mathrm{a}}$ extracellular adenosine receptor-mediated signaling in adenosine-mediated inhibition of T-cell activation and expansion. Blood 1997; 90: 16001610.

20. Cronstein BN. Adenosine regulation of neutrophil function and inhibition of inflammation via adenosine receptors. In: Jacobson KA, Jarvis MF, eds. Purinergic Approaches in Experimental Therapeutics. New York, Wiley-Liss, 1997; pp. 285-293.

21. Eppell BA, Newell AM, Brown EJ. Adenosine receptors are expressed during differentiation of monocytes to macrophages in vitro: implications for regulation of phagocytosis. J Immunol 1989; 143 : 4141-4145.

22. Hasko G, Szabo C, Nemeth ZH, Kvetan V, Pastores SM, Vizi ES. Adenosine receptor agonists differentially regulate IL-10, TNF- $\alpha$, and nitric oxide production in RAW 264.7 macrophages and in endotoxemic mice. J Immunol 1996; 157: 46344640.

23. Pauwels R, Van Der Straeten M. An animal model for adenosine-induced bronchoconstriction. Am Rev Respir Dis 1987; 136: 374-378.

24. Polosa R, Phillips GD, Rajakulasingam K, Holgate ST. The effect of inhaled ipratropium bromide alone and in combination with oral terfenadine on bronchoconstriction provoked by adenosine $5^{\prime}$-monophosphate in asthma. J Allergy Clin lmmunol 1991; 87: 939947.

25. Polosa R. Inhaled loop diuretics: How do we interpret their modulatory role in asthma? Allergy 1993; 48: 555-558.

26. Polosa R, Lau LCK, Holgate ST. Inhibition of adenosine 5'-monophosphate and methacholine-induced bronchoconstriction in asthma by inhaled frusemide. Eur Respir J 1990; 3: 665-672.

27. O'Connor BJ, Chung KF, Miin Chen-Worsdell YM, Fuller RW, Barnes PJ. Effect of inhaled furosemide and bumetanide on adenosine 5'-monophosphate- and sodium metabisulphite-induced bronchoconstriction in asthmatic subjects. Am Rev Respir Dis 1991; 143: 1329-1333.

28. Polosa R, Rajakulasingam K, Prosperini G, Church MK, Holgate ST. Relative potencies and time-courses of changes in AMP airway responsiveness with inhaled frusemide and bumetanide in asthma. J Allergy Clin Immunol 1993; 92: 288-297.

29. Manzini S, Ballati L. 2-chloroadenosine induction of vagally-mediated and atropine-resistant bronchomotor responses in anaesthetised guinea pigs. $\mathrm{Br} J$ Pharmacol 1990; 100: 251-256.

30. Meade CJ, Mierau J, Leon I, Ensinger HA. In vivo role of the adenosine $\mathrm{A} 3$ receptor: $\mathrm{N}^{6}-2-(4$-aminophenyl)ethyladenosine induces bronchospasm in BDE rats by a neurally mediated mechanism involving cells resembling mast cells. J Pharmacol Exp Ther 1996; 279: 1148-1156.

31. Polosa R, Rajakulasingam K, Church MK, Holgate ST. Repeated inhalation of bradykinin attenuates 
adenosine 5'-monophosphate (AMP) induced bronchoconstriction in asthmatic airways. Eur Respir J 1992; 5: 700-706.

32. Polosa R, Santonocito G, Magrì S, et al. A study of NEP inhibition with inhaled phosphoramidon on bronchial responsiveness to AMP in asthma. Eur Respir J 1997; 10: 2460-2464.

33. Rutgers SR, Koeter GH, van der Mark TW, Postma DS. Protective effect of oral terfenadine and not inhaled ipratropium on AMP-induced bronchoconstriction in patients with COPD. Clin Exp Allergy 1999; 29: 1287-1292.

34. Church MK, Pao GJ-K, Holgate ST. Characterisation of histamine secretion from mechanically dispersed human lung mast cells: effects of anti-IgE, calcium ionophore A23187, compound 48/80 and basic polypeptides. J Immunol 1982; 129: 2116-2121.

35. Peachell PT, Columbo M, Kagey-Sabotka A, Lichtenstein LM, Marone G. Adenosine potentiates mediator release from human lung mast cells. Am Rev Respir Dis 1988; 138: 1143-1151.

36. Forsythe P, McGarvey LPA, Heaney LG, MacMahon $\mathrm{J}$, Ennis M. Adenosine induces histamine release from human BAL mast cells. Clin Sci 1999; 96: 349-355.

37. Phillips GD, Scott VL, Richards R, Holgate ST. Effect of nedocromil sodium and sodium cromoglycate against bronchoconstriction induced by inhaled adenosine 5'-monophosphate. Eur Respir J 1989; 2: 210-217.

38. Phillips GD, Finnerty JP, Holgate ST. Comparative protective effect of the inhaled $\beta_{2}$-agonist salbutamol (albuterol) on bronchoconstriction provoked by histamine, methacholine and adenosine 5-monophosphate in asthma. J Allergy Clin Immunol 1990; 85: 755-762.

39. Rafferty P, Beasley R, Holgate ST. The contribution of histamine to immediate bronchoconstriction provoked by inhaled allergen and adenosine $5^{\prime}$ monophosphate in atopic asthma. Am Rev Respir Dis 1987; 136: 369-373.

40. Phillips GD, Polosa R, Holgate ST. The effect of histamine $\mathrm{H}_{1}$ receptor antagonism with terfenadine on concentration-related AMP-induced bronchoconstriction in asthma. Clin Exp Allergy 1989; 19: 405-409.

41. Crimi N, Palermo F, Polosa R, et al. Effect of indomethacin on adenosine-induced bronchoconstriction. J Allergy Clin Immunol 1989; 83: 921-925.

42. van Schoor J, Joos GF, Kips JC, Drajesk JF, Carpentier PJ, Pauwels RA. The effect of ABT-761, a novel 5-lipoxygenase inhibitor, on exercise- and adenosine-induced bronchoconstriction in asthmatic subjects. Am J Respir Crit Care Med 1997; 155: 875880 .

43. Bodansky O, Schwartz MJ. 5'-nucleotidase. Adv Clin Chem 1968; 11: 277-328.

44. Mentzer RM, Rubio R, Berne RM. Release of adenosine from hypoxic canine lung tissue and its possible role in the pulmonary circulation. $A m J$ Physiol 1975; 229: 1625-1631.

45. Arch JRS, Newsholme EA. The control of the metabolism and the hormonal role of adenosine. Essays Biochem 1978; 14: 82-123.

46. Trams EG, Lauter CJ. On the sidedness of plasma membrane enzymes. Biochem Biophys Acta 1974; 345: 180-197.

47. Plagemann PG, Richey DP. Transport of nucleosides, nucleic acid bases, choline and glucose by animal cells in culture. Biochem Biophys Acta 1974; 344: 263-305.
48. Olah ME, Stiles GL. Adenosine receptor subtypes: characterization and therapeutic regulation. Аnпu Rev Pharmacol Toxicol 1995; 35: 581.

49. Stafford A. Potentiation of adenosine and the adenine nucleotides by dipyridamole. Br J Pharmac Chemother 1966; 28: 218-227.

50. Crimi N, Palermo F, Oliveri R, et al. Enhancing effect of dipyridamole inhalation on adenosine-induced bronchospasm in asthmatic patients. Allergy 1988; 43: 179-183.

51. Van Calker D, Muller M, Hamprecht B. Adenosine regulates, via two different types of receptor, the accumulation of cyclic AMP in cultured brain cells. J Neurochem 1979; 33: 999-1005.

52. Londos C, Cooper DMF, Wolff J. Subclasses of external adenosine receptors. Proc Natl Acad Sci USA 1980; 77: 2551-2554.

53. Salvatore CA, Jacobson MA, Taylor HE, Linden J, Johnson RG. Molecular cloning and characterization of the human A3 adenosine receptor. Proc Natl Acad Sci USA 1993; 90: 10365-10369.

54. Pierce KD, Furlong TJ, Selbie LA, Shine J. Molecular cloning and expression of an adenosine $\mathrm{A}_{2 \mathrm{~B}}$ receptor from human brain. Biochem Biophys Res Comm 1992; 187: 86-93.

55. Robeva AS, Woodard RL, Jin XW, et al. Molecular characterization of recombinant human adenosine receptors. Drug Dev Res 1996; 39: 243-252.

56. Linden J, Thai I, Figler $\mathrm{H}$, Jin X, Robeva AS. Characterization of human $\mathrm{A}(2 \mathrm{~B})$ adenosine receptors: radioligand binding, western blotting and coupling to G(q) in human embryonic kidney 203 cells and HMC-1 mast cells. Mol Pharmacol 1999; 56: 705713.

57. Feoktistov I, Biaggioni I. Pharmacological characterization of adenosine $A_{2 B}$ receptors. Studies in human mast cells co-expressing $\mathrm{A}_{2 \mathrm{~A}}$ and $\mathrm{A}_{2 \mathrm{~B}}$ adenosine receptor subtypes. Biochem Pharmacol 1998; 55: 627633.

58. Feoktistov I, Biaggioni I. Adenosine $A_{2 B}$ receptors evoke interleukin-8 secretion in human mast cells - An enprofylline-sensitive mechanism with implications for asthma. J Clin Invest 1995; 96: 1979-1986.

59. Klotz K-N, Hessling J, Hegler J, et al. Comparative pharmacology of human adenosine receptor subtypes - characterization of stably transfected receptors in CHO cells. Naunyn Schmiedeberg's Arch Pharmacol 1998; 357: 1-9.

60. Metzger WJ, Nyce JW. Oligonucleotide therapy of allergic asthma. J Allergy Clin Immunol 1999; 104: 260-266.

61. Collins MG, Hourani SMO. Adenosine receptor subtypes. Trends Pharmacol Sci 1993; 14: 361-366.

62. Cronstein BN, Daguma L, Nichols D, Hutchison AJ, Williams $M$. The adenosine/neutrophil paradox resolved: human neutrophils possess both $\mathrm{A}_{1}$ and $\mathrm{A}_{2}$ receptors that promote chemotaxis and inhibit $\mathrm{O}_{2}$ generation, respectively. Clin Invest 1990; 85: 1150 1157.

63. Cronstein BN, Levin RI, Phillips NI, Hirschhorn R, Abramson SB, Weissman G. Neutrophil adherence to endothelium is enhanced via adenosine $\mathrm{A}_{1}$ receptors and inhibited via adenosine $\mathrm{A}_{2}$ receptors. J Immunol 1992; 148: 2201-2206.

64. Felsch A, Stocker K, Borchard U. Phorbol esterstimulated adherence of neutrophils to endothelial 
cells is reduced by adenosine $\mathrm{A}_{2}$ receptor agonists. J Immunol 1995; 155: 333-338.

65. Ali S, Mustafa SJ, Metzger WJ. Adenosine-induced bronchoconstriction and contraction of airway smooth muscle from allergic rabbits with late-phase airway obstruction: evidence for an inducible adenosine $\mathrm{A}_{1}$ receptor. J Pharmacol Exp Ther 1994; 268: $1328-1334$.

66. El-Hashim A, D'Agostino B, Matera MG, Page C. Characterization of adenosine receptors involved in adenosine-induced bronchoconstriction in allergic rabbits. Br J Pharmacol 1996; 119: 1262-1268.

67. Nyce JW, Metzger WJ. DNA antisense therapy for asthma in an animal model. Nature 1997; 385: 721725 .

68. Suzuki H, Takei M, Nakahata T, Fukamachi $H$. Inhibitory effect of adenosine on degranulation of human cultured mast cells upon cross-linking of FceRI. Biochem Biophys Res Commun 1998; 242: 697-702.

69. Varani K, Gessi S, Dionisotti S, Ongini E, Borea PA. (3H)-SCH 58261 labelling of functional A2A adenosine receptors in human neutrophil membranes. $\mathrm{Br}$ J Pharmacol 1998; 123: 1723-1731.

70. Varani K, Gessi S, Dalpiaz A, Ongini E, Borea PA. Characterization of $\mathrm{A} 2 \mathrm{~A}$ adenosine receptors in human lymphocyte membranes by $(3 \mathrm{H})-\mathrm{SCH} 58261$ binding. Br J Pharmacol 1997; 122: 386-392.

71. Hughes PJ, Holgate ST, Church MK. Adenosine inhibits and potentiates $\operatorname{IgE}$ dependent histamine release from human lung mast cells by an A2purinoceptor mediated mechanism. Biochem Pharmacol 1984; 33: 3847-3852.

72. Peachell PT, Lichtenstein LM, Scheimer RP. Regulation of human basophil and lung mast cell function by adenosine. J Pharmacol Exp Ther 1991; 256: 717-726.

73. Wollner A, Wollner S, Smith JB. Acting via $\mathrm{A}_{2}$ receptors adenosine inhibits the upregulation of Mac1 (CD11b/CD18) expression on fMLP stimulated neutrophils. Am J Respir Cell Mol Biol 1993; 9: 179185.

74. Fredholm BB, Zhang Y, Van Der Ploeg L. Adenosine $\mathrm{A}_{2 \mathrm{~A}}$ receptors mediate the inhibitory effect of adenosine on formyl-Met-Leu-Phe stimulated respiratory burst in neutrophil leucocytes. Naunyn-Schmiedeberg's Arch Pharmacol 1996; 354: 262-267.

75. Hannon JP, Bray-French KM, Phillips RM, Fozard JR. Further pharmacological characterization of the adenosine receptor subtype mediating inhibition of oxidative burst in isolated human neutrophils. Drug Dev Res 1998; 43: 214-224.

76. Bouma MG, Stad RK, Van Den Wildenberg F, Buman WA. Differential regulatory effects of adenosine on cytokine release by activated human monocytes. J Immunol 1994; 153: 4159-4168.

77. Collis MG, Hourani SMO. Adenosine receptor subtypes. Trends Pharmacol Sci 1993; 14: 361-366.

78. Ledent C, Vaugeois JM, Schiffmann SN, et al. Aggressiveness, hypoalgesia and high blood pressure in mice lacking the adenosine $\mathrm{A}_{2 \mathrm{~A}}$ receptor. Nature 1997; 388: 674-678.

79. Feoktistov I, Goldstein AE, Biaggioni I. Role of p38 mitogen-activated protein kinase and extracellular signal-regulated protein kinase kinase in adenosine $\mathrm{A}_{2 \mathrm{~B}}$ receptor-mediated interleukin-8 production in human mast cells. Mol Pharmacol 1999; 55: 726-734.

80. Clancy JP, Ruiz FE, Sorscher EJ. Adenosine and its nucleotides activate wild-type and R117H CFTR through an $\mathrm{A}_{2 \mathrm{~B}}$ receptor-coupled pathway. $\mathrm{Am} J$ Physiol 1999; 276: C361-C369.

81. Feoktistov I, Biaggioni I. Adenosine $A_{2 B}$ receptors. Pharmacol Rev 1997; 49: 381-402.

82. Mundell SJ, Olah ME, Panettieri RA Jr, Benovic JL, Penn RB. Regulation of $G$ protein-coupled receptor adenylyl cyclase responsiveness in human airway smooth muscle by exogenous and autocrine adenosine. Am J Respir Cell Mol Biol 2001; 24: 155-163.

83. Mann JS, Holgate ST. Specific antagonism of adenosine-induced bronchoconstriction in asthma by oral theophylline. Br J Clin Pharmacol 1985; 19: 685692.

84. Clarke H, Cushley MJ, Persson CG, Holgate ST. The protective effects of intravenous theophylline and enprofylline against histamine and adenosine 5'-monophosphate-provoked bronchoconstriction: Implications for the mechanisms of action of xanthine derivatives in asthma. Pulm Pharmacol 1989; 2: 147154 .

85. Thorne JR, Danahay H, Broadley KJ. Analysis of the bronchoconstrictor responses to adenosine receptor agonists in sensitized guinea-pig lungs and trachea. Eur J Pharmacol 1996; 316: 263-271.

86. Fozard JR, Pfannkuche H-J, Schuurman H-J. Mast cell degranulation following adenosine $\mathrm{A}_{3}$ receptor activation in rats. Eur J Pharmacol 1996; 298: 293297.

87. Shepherd RK, Linden J, Duling BR. Adenosineinduced vasoconstriction in vivo. Role of the mast cell and $\mathrm{A}_{3}$ adenosine receptor. Circ Res 1996; 78 : 627-634.

88. Kohno Y, Ji X, Mawhorter SD, Koshiba M, Jacobson KA. Activation of $\mathrm{A}_{3}$ adenosine receptors on human eosinophils elevates intracellular calcium. Blood 1996; 88: 3569-3574.

89. Knight K, Zheng X, Rocchini C, Jacobson M, Bai T, Walker BA. Adenosine $\mathrm{A}_{3}$ receptor stimulation inhibits migration of human eosinophils. J Leukoc Biol 1997; 62: 465-468.

90. Ezeamuzie CI, Philips E. Adenosine $\mathrm{A}_{3}$ receptors on human eosinophils mediate inhibition of degranulation and superoxide anion release. Br J Pharmacol 1999; 127: 188-194.

91. Le-Vraux V, Chen YL, Masson I, et al. Inhibition of human monocyte TNF production by adenosine receptor agonists. Life Sci 1993; 52: 1917-1924.

92. Gessi S, Varani K, Merighi S, et al. Pharmacological and biochemical characterization of A3 adenosine receptors in Jurkat T cells. Br J Pharmacol 2001; 134: 116-126. 